\title{
Gambaran Derajat Dehidrasi dan Gangguan Fungsi Ginjal pada Diare Akut
}

\author{
Sulaiman Yusuf, ${ }^{*}$ Syafruddin Haris, ${ }^{*}$ Muzal Kadim** \\ *Bagian Ilmu Kesehatan Anak Fakultas Kedokteran Universitas Syiah Kuala/RSUD Zainoel Abidin, \\ Banda Aceh \\ *** Departemen Ilmu Kesehatan Anak Fakultas Kedokteran Universitas Indonesia/RS. Cipto \\ Mangunkusumo, Jakarta
}

Latar belakang. Diare akut merupakan salah satu masalah kesehatan yang cukup banyak ditemukan pada bayi dan anak. Gejala utamanya dehidrasi atau kekurangan cairan dalam tubuh sehingga menyebabkan penurunan volume ekstraselular yang menyebabkan berkurangnya perfusi jaringan memicu gangguan fungsi organ-organ tubuh salah satunya penurunan fungsi ginjal.

Tujuan. Mengetahui gambaran derajat dehidrasi dan gangguan fungsi ginjal pada diare akut.

Metode. Penelitian deskriptif dengan pendekatan cross sectional yang ditujukan untuk membuat deskripsi atau gambaran derajat dehidrasi dari diare akut dan gangguan fungsi ginjal pada pasien rawat inap anak Rumah Sakit Umum Daerah Dr. Zainoel Abidin (RSUDZA) Banda Aceh. Penelitian dilakukan pada Agustus sampai dengan bulan Desember 2010 dengan pengumpulan data, klasifikasi, dilanjutkan dengan analisis data.

Hasil. Didapatkan 21 pasien diare akut yang memenuhi kriteria penelitian. Jumlah pasien berusia $<2$ tahun 17, umur 2-15 tahun 4 anak. Jenis kelamin laki-laki 12 dan perempuan 4. Berdasarkan derajat dehidrasi didapatkan pasien diare akut tanpa dehidrasi 8 , dehidrasi ringan sedang 11 , dan dehidrasi berat 2. Laju filtrasi glomerulus (LFG) berdasarkan kriteria RIFLE ditemukan pasien diare akut dengan risk 6, dan injury 1. Terdapat 2 masuk kriteria risk dari 8 pasien diare akut tanpa dehidrasi, 3 masuk kriteria risk dari 11 pasien diare akut dehidrasi ringan sedang, dan 1 masuk kriteria injury dari 2 pasien diare akut dengan dehidrasi berat.

Kesimpulan. Semakin berat derajat dehidrasi maka semakin tinggi risiko terjadi gangguan fungsi ginjal. Sari Pediatri 2011;13(3):221-5.

Kata kunci: diare, dehidrasi, laju filtrasi glomerulus, gangguan fungsi ginjal

Alamat korespondensi:

dr. Sulaiman Yusuf, SpA. Divisi Gastroentero-Hepatologi BIKA FK Unsyiah/RSUDZA Banda Aceh, Jl. Tgk Daud Beureueh No. 108, Banda Aceh, HP. 0811683194, E-mail: sly_adan@yahoo.com

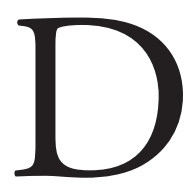
i seluruh dunia, diare merupakan masalah kesehatan utama, lebih dari 4 juta orang meninggal karena diare setiap tahunnya. Di negara berkembang, diare diperkirakan merenggut nyawa 10.000 anak usia di bawah 5 tahun setiap harinya. ${ }^{1}$ Anak balita mengalami rata-rata 3-4 
kali kejadian diare per tahun, di beberapa tempat terjadi lebih dari 9 kali kejadian diare per tahun atau hampir 15\%-20\% waktu hidup anak dihabiskan untuk diare. ${ }^{2}$

Di Indonesia, diare adalah penyebab kematian balita nomor dua setelah ISPA (infeksi saluran pernapasan akut). ${ }^{3}$ Disebabkan karena angka kesakitan diare masih tinggi sehingga menimbulkan banyak kematian terutama pada balita. Angka kesakitan diare di Indonesia dari tahun ke tahun cenderung meningkat. Diperkirakan angka kesakitan berkisar antara 150-430 per seribu penduduk setahunnya. ${ }^{4}$ Dapat ditemukan kasus diare sekitar 60 juta kejadian setiap tahun di Indonesia. Sebagian besar (70\%-80\%) kasus adalah anak di bawah 5 tahun (lebih kurang 40 juta kejadian). Sebagian dari kasus (1\%-2\%) akan jatuh ke dalam dehidrasi, dan bila tidak segera ditolong 50\%-60\% di antaranya dapat meninggal. ${ }^{5}$

Hasil Riset Kesehatan Dasar (RISKESDAS) tahun 2007 menyatakan prevalensi nasional diare klinis (berdasarkan diagnosis tenaga kesehatan dan gejala) adalah 9,0\% dengan rentang 4,2\%-18,9\%. Empat belas provinsi mempunyai prevalensi diare di atas prevalensi nasional, dengan prevalensi tertinggi terjadi di Aceh dan terendah di Yogyakarta. ${ }^{3}$

Di Aceh pada tahun 2008 proporsi kasus diare pada balita mencapai $44,5 \%$ yaitu dengan jumlah 58.116 kejadian, sedangkan pada tahun $2007,44,3 \% .{ }^{6}$ Sementara itu, data dari RSUDZA Banda Aceh menunjukkan jumlah pasien diare akut pada tahun 2009 di ruang rawat inap anak mencapai 98 anak.

Berdasarkan hasil penelitian Dwipoerwantoro ${ }^{7}$ tentang pola tata laksana diare akut di beberapa rumah sakit swasta di Jakarta pada tahun 1999, didapatkan $13 \%$ dari seluruh pasien diare akut mengalami dehidrasi berat. Penelitian di Bali pada tahun 2004 mendapatkan 3\% pasien yang menderita diare akut dehidrasi berat, dengan $58 \%$ mengalami asidosis metabolik, ensefalopati $47 \%$, hipernatremi $42 \%$, hiponatremi $18 \%$, dan hipokalemi $15 \%$.

Dehidrasi atau kekurangan cairan dalam tubuh memicu gangguan kesehatan. Mulai dari gangguan ringan seperti mudah mengantuk, hingga penyakit berat seperti penurunan fungsi ginjal. ${ }^{8}$ Bila pada diare pengeluaran cairan melebihi pemasukan maka akan terjadi defisit cairan tubuh, yang disebut juga dengan dehidrasi. Pada dehidrasi berat terjadi defisit cairan sama dengan atau lebih dari 10\% berat badan. ${ }^{7,9}$ Anak dan terutama bayi memiliki risiko yang lebih besar untuk menderita dehidrasi dibandingkan orang dewasa. ${ }^{10}$
Pada diare akut dengan dehidrasi berat, volume darah berkurang sehingga dapat terjadi dampak negatif pada bayi dan anak gejalanya antara lain renjatan hipovolemik (denyut jantung menjadi cepat, denyut nadi cepat, kecil, tekanan darah menurun, penderita menjadi lemah, kesadaran menurun, diuresis berkurang), gangguan elektrolit, gangguan keseimbangan asam basa, dan gagal ginjal akut. ${ }^{4,7}$

Berdasarkan uraian di atas maka penulis melakukan penelitian untuk mengetahui gambaran derajat dehidrasi pada diare akut dan gangguan fungsi ginjal.

\section{Metode}

Penelitian merupakan studi deskriptif dengan pendekatan cross sectional. Tujuan untuk melihat gambaran derajat dehidrasi dari diare akut dan gangguan fungsi ginjal pada pasien di Ruang Rawat Inap Anak di RSUDZA Banda Aceh, periode AgustusDesember 2010. Populasi penelitian adalah semua pasien bayi dan anak yang menderita diare akut yang dirawat di Ruang Rawat Inap Anak di RSUDZA Banda Aceh. Pengambilan sampel menggunakan metode total sampling. Kriteria inklusi yaitu bayi usia $>1$ bulan hingga usia 15 tahun yang telah didiagnosis dengan diare akut tanpa dehidrasi, dehidrasi ringan sedang, dan dehidrasi berat yang mempunyai data hasil pemeriksaan ureum dan kreatinin serta laju filtrasi glomerulus (LFG). Orang tua pasien menyetujui dan menandatangani informed consent untuk menjadi subjek penelitian. Sedangkan kriteria eksklusi adalah pasien bayi dan anak yang menderita diare akut disertai penyakit lain. Data primer, diperoleh dari hasil pemeriksaan laboratorium fungsi ginjal yaitu dinilai dari kadar ureum, kreatinin dan laju filtrasi glomerulus (LFG). Data dianalisis dengan analisis univariat yang dilakukan terhadap tiap variabel dari hasil penelitian untuk melihat nilai rata-rata, nilai minimal dan maksimal serta distribusi frekuensi.

\section{Hasil}

Didapatkan 21 pasien diare akut yang memenuhi kriteria penelitian. Karakteristik umur responden dibagi menjadi dua yaitu kategori umur di bawah 2 tahun dan umur 2-15 tahun (Tabel 1). 
Jumlah pasien berjenis kelamin laki-laki 12 responden dan perempuan 9 responden. Berdasarkan derajat dehidrasi responden dibagi menjadi tiga yaitu tanpa dehidrasi, dehidrasi ringan sedang, dan dehidrasi berat. Dari hasil yang didapatkan 11 responden mengalami diare dengan dehidrasi ringan sedang (Tabel 2).

Dari Tabel 2 terlihat pasien diare yang tanpa dehidrasi 8 responden, dehidrasi ringan sedang 11 responden, dan dehidrasi berat 2 responden. Berdasarkan jumlah ureum dalam darah responden dibagi menjadi dua kelompok umur yaitu usia di bawah 1 tahun dan usia $1-15$ tahun.

Pasien diare pada kelompok umur kurang dari 1 tahun sebagian besar memiliki tingkat ureum $11 \mathrm{mg} / \mathrm{dl}$ dan $15 \mathrm{mg} / \mathrm{dl}$. Sedangkan pada kelompok umur 1-15 tahun sebagian besar memiliki tingkat ureum $6 \mathrm{mg} / \mathrm{dl}$. Berdasarkan jumlah kreatinin dalam darah responden dibagi menjadi dua kelompok umur yaitu usia di

Tabel 1. Distribusi responden berdasarkan umur dan jenis kelamin

\begin{tabular}{lc}
\hline Karakteristik & Frekuensi \\
\hline Umur (tahun) & \\
$<2$ & 17 \\
$2-15$ & 4 \\
Jenis kelamin & \\
Laki-laki & 12 \\
Perempuan & 9 \\
\hline
\end{tabular}

Tabel 2. Distribusi responden berdasarkan derajat dehidrasi

\begin{tabular}{lc}
\hline Derajat dehidrasi & Frekuensi \\
\hline Tanpa dehidrasi & 8 \\
Dehidrasi ringan sedang & 11 \\
Dehidrasi berat & 2 \\
\hline Total & 21 \\
\hline
\end{tabular}

Tabel 3. Distribusi responden berdasarkan jenis kelamin

\begin{tabular}{lc}
\hline Kriteria RIFLE & Frekuensi \\
\hline Risk & 6 \\
Injury & 1 \\
Failure & 0 \\
Loss & 0 \\
End stage & 0 \\
\hline Total & 7 \\
\hline
\end{tabular}

bawah 1 tahun dan usia 1-15 tahun. Pada kelompok umur kurang dari 1 tahun sebagian besar memiliki tingkat kreatinin $0,5 \mathrm{mg} / \mathrm{dl}$, sedangkan pada kelompok umur $1-15$ tahun $0,5 \mathrm{mg} / \mathrm{dl}$. Berdasarkan perhitungan LFG dengan formula Schwartz, ${ }^{13}$ didapatkan hasil LFG pasien. Pembagian LFG berdasarkan kriteria RIFLE, ${ }^{14}$ dibagi menjadi lima yaitu risk, injury, failure, loss, dan end stage (Tabel 3). Terdapat 6 responden dari pasien diare dengan risk, 1 responden injury, dan tidak terdapat responden failure, loss, dan end stage.

\section{Pembahasan}

Telah dilakukan penelitian deskriptif cross sectional dengan menggunakan data primer yang dikumpulkan secara langsung, kemudian diolah dan dianalisis. Penelitian menggunakan metode kuantitatif dengan keterbatasan penelitian,(1) Rancangan penelitian deskriptif dengan pendekatan cross sectional sehingga hanya menyuguhkan sejelas mungkin fenomena sewaktu, tanpa mencoba menganalisis mengapa dan bagaimana fenomena tersebut terjadi. (2) Kemungkinan adanya bias penelitian, antara lain karena batasan umur responden anak yang cukup besar, jumlah pasien diare yang terbatas, dan pasien tidak melakukan puasa pemeriksaan fungsi ginjal. Dengan adanya keterbatasan tersebut maka hasil interpretasi harus dilakukan dengan hati-hati dan selain itu masih diperlukan lagi beberapa data penunjang lain, seperti penelitian sebelumnya untuk memperkuat hasil penelitian.

Kelompok umur terendah yang menderita diare akut adalah usia 2 bulan dan yang tertinggi usia 4 tahun. Umur adalah variabel yang selalu diperhatikan dalam penyelidikan epidemiologi. Angka kesakitan maupun kematian pada hampir semua keadaan menunjukkan hubungan dengan umur. Tingginya angka kesakitan pada bayi dan anak karena anak dan terutama bayi memiliki risiko yang lebih besar untuk menderita dehidrasi dibandingkan orang dewasa. ${ }^{10}$ Menurut Jannah ${ }^{15}$ tahun 2005, umur mempunyai kaitan dengan daya tahan tubuh. Pada umumnya daya tahan tubuh orang dewasa jauh lebih kuat dari daya tahan tubuh bayi dan anak. Sebagaimana penelitian yang dilakukan Dwipoerwantoro ${ }^{7}$ di ruang rawat inap anak Rumah Sakit dr. M. Djamil Padang dari 258 kasus diare akut hanya $7,17 \%$ berkembang menjadi diare akut dehidrasi berat. 
Pasien laki-laki 12 responden dan perempuan 9 responden. Di luar negeri angka kesakitan lebih tinggi pada kalangan perempuan sedangkan angka kematian lebih tinggi pada kalangan laki-laki juga pada semua golongan umur. Untuk Indonesia masih perlu dipelajari lebih lanjut. Perbedaan angka kematian ini, dapat disebabkan oleh faktor-faktor intrinsik. ${ }^{15}$ Sebagaimana penelitian yang dilakukan Jurnalis ${ }^{7}$ jenis kelamin laki-laki lebih banyak dari perempuan $(75,9 \%$ vs $24,1 \%) .^{7}$ Sedangkan berdasarkan penelitian Mahalini pada tahun 2004 di Bali juga mendapatkan laki-laki lebih banyak dari perempuan (60\% vs $40 \%)$. Pada kasus tertentu jenis kelamin mempengaruhi terjadinya penyakit akan tetapi pada kasus diare jenis kelamin tidak mempengaruhi kejadian diare.

Berdasarkan hasil penelitian didapatkan pasien diare paling banyak mengalami diare dengan dehidrasi ringan sedang. Pada diare, dehidrasi menyebabkan penurunan volume ekstraselular yang menyebabkan perfusi jaringan berkurang. Peningkatan kecepatan nadi terjadi sebagai kompensasi karena jantung berusaha untuk meningkatkan keluaran (output) dalam menghadapi volume pukulan (stroke volume) yang berkurang. Perfusi jaringan yang berkurang juga menghambat fungsi ginjal sehingga menyebabkan asidosis dan uremia (pada diare asidosis diperberat dengan kehilangan bikarbonat). Penyampaian oksigen pada jaringan menyebabkan pula asidosis laktat. Apabila terdapat pengurangan dalam pemasukan kalori yang menyertainya atau ketidakmampuan untuk menstabilisasi kalori yang masuk, dapat timbul ketoasidosis. ${ }^{5}$

Sebagian besar kasus kami mempunyai kadar ureum dan kreatinin normal. Enam diantara 21 kasus termasuk kriteria risk dan injury. Menurut Andreoli ${ }^{16}$ tahun 2009 pada faktor prerenal, fungsi ginjal terganggu karena berkurangnya perfusi ginjal, sedangkan ginjal dalam keadaan normal. Semua faktor yang menyebabkan peredaran darah ke ginjal berkurang dengan terdapatnya hipovolemia, ${ }^{17}$ misalnya perdarahan karena trauma operasi, dehidrasi atau berkurangnya volume cairan ekstraselular (dehidrasi pada diare), dan berkumpulnya cairan interstitial di suatu daerah luka (kombustio, pasca-bedah yang cairannya berkumpul di daerah operasi, peritonitis dan proses eksudatif lain yang menyebabkan hipovolemia). Bila faktor prerenal dapat diatasi, maka faal ginjal menjadi normal kembali. Tetapi bila hipovolemia berlangsung terlampau lama, maka akan terjadi kerusakan pada parenkim ginjal. Faktor prarenal bisa menimbulkan penurunan LFG dan peningkatan serum kreatinin tanpa menimbulkan kerusakan pada jaringan di ginjal. ${ }^{18}$

\section{Kesimpulan}

Separuh dari kasus yang kami rawat menderita diare dengan dehidrasi ringan. Sebagian besar mempunyai kadar ureum dan kreatinin normal. Dua pasien diare dengan dehidrasi berat satu masuk dalam kriteria injury. Semakin berat derajat dehidrasi maka semakin tinggi risiko terjadi gangguan fungsi ginjal.

\section{Daftar pustaka}

1. Gough JE, Clement PA. Diarrheal. Dalam: Marx JA, penyunting. Rosen's emergency. Edisi keenam. Philadelphia. Mosby Elsevier; 2006. h. 227-36.

2. Wulandari, AP. Hubungan antara faktor lingkungan dan faktor sosiodemografi dengan kejadian diare pada balita di desa Blimbing Kecamatan Sambirejo Kabupaten Sragen Tahun 2009. Skripsi. Universitas Muhammadiyah Surakarta. 2009.

3. Departemen Kesehatan RI. Profil kesehatan Indonesia 2008. Jakarta. 2009.

4. Latief, A. Buku kuliah ilmu kesehatan anak jilid I dan II. Edisi II. Jakarta: Bagian Ilmu Kesehatan Anak FKUI; 2007.

5. Irwanto, Rohim A, Sudarmo SM. Diare akut pada anak. Dalam: Soegijanto, S, penyunting. Ilmu penyakit anak diagnosa dan penatalaksanaan. Jakarta: Penerbit Salemba Medika; 2002.h.73-91.

6. Dinas Kesehatan Aceh. Profil Kesehatan Provinsi Nanggroe Aceh Darussalam tahun 2009. Aceh. 2009.

7. Dwipoerwantoro PG, Hegar B, Pustika AW, Witjaksono. Pola tata laksana diare akut di beberapa rumah sakit swasta di Jakarta; apakah sesuai dengan protokol WHO? Sari Pediatri 2055;6:182-7.

8. Noorastuti PT, Nugraheni M. Kenali bahaya dehidrasi Kekurangan cairan tubuh sekitar dua persen sudah memicu gangguan kesehatan. http://www.vivanews.com/ news/read/153985-kenali bahaya dehidrasi, 2010. Diakses pada: 28 November 2010. 
9. WHO. Pelayanan kesehatan anak di rumah sakit pedoman bagi rumah sakit rujukan tingkat pertama di kabupaten/kota. WHO dan Departemen Kesehatan RI. Jakarta. 2009.

10. Rudolph JA, Rufo PA. Diarrhea. Dalam: Benson JB, Haith MM; Disease and disorder in infancy and early childhood. Edisi pertama. San Diego: Elsevier; 2004. h. 130-7.

11. Notoatmodjo, S. Metodologi penelitian kesehatan. Edisi ketiga. Rineka Cipta. Jakarta. 2005.

12. Pratiknya, AW. Dasar-dasar metodologi penelitian kedokteran dan kesehatan. PT. Raja Grafindo Persada. Jakarta. 2008.

13. Lubis, IN. Handbook for Pediatrician. Medan. 2007.

14. Holley JL. Clinical approach to the diagnosis of acute renal failure. Dalam : Greenberg A, penyunting. Primer on kidney disease. Edisi kelima. Philadelphia: Elsevier; 2009.
15. Jannah R. Gambaran penderita diare serta karakteristik yang berobat pada bulan Juli di Puskesmas Peusangan Kabupaten Bireun tahun 2005. Skripsi. Universitas Muhammadiyah Aceh. 2005.

16. Andreoli SP. Clinical evaluation of acute kidney injury in children. Dalam: Avner E, penyunting. Pediatric nephrology. Edisi keenam. Berlin: Springer-Verlag Berlin Heidelberg; 2009. h. 1603-18.

17. Phan V, Brophy PD, Fleming GM. Acute Renal failure: prevention, causes, and investigation. Dalam: Geary DF, Schaefer F, penyunting. Comprehensive pediatric nephrology. Philadelphia: Mosby Elsevier; 2008. h. 607-27.

18. Coca SG, Parikh CR. Urinary biomarkers for acute kidney injury: perspective on translation. Clin J Am Soc Nephrol 2008;3:481-90. 